This item was submitted to Loughborough's Research Repository by the author.

Items in Figshare are protected by copyright, with all rights reserved, unless otherwise indicated.

\title{
Relationships among nutrient enrichment, detritus quality and quantity, and large-bodied shredding insect community structure
}

PLEASE CITE THE PUBLISHED VERSION

https://doi.org/10.1007/s10750-015-2208-2

\section{PUBLISHER}

(C) Springer

VERSION

AM (Accepted Manuscript)

\section{PUBLISHER STATEMENT}

This work is made available according to the conditions of the Creative Commons Attribution-NonCommercialNoDerivatives 4.0 International (CC BY-NC-ND 4.0) licence. Full details of this licence are available at: https://creativecommons.org/licenses/by-nc-nd/4.0/

\section{LICENCE}

CC BY-NC-ND 4.0

\section{REPOSITORY RECORD}

Prater, Clay, Eric J. Norman, and Michelle A. Evans-White. 2019. "Relationships Among Nutrient Enrichment, Detritus Quality and Quantity, and Large-bodied Shredding Insect Community Structure". figshare. https://hdl.handle.net/2134/28330. 


\title{
Relationships among nutrient enrichment, detritus quality and quantity, and large-bodied shredding insect community structure
}

\author{
Clay Prater $^{1 *}$, Eric J. Norman ${ }^{1}$, Michelle A. Evans-White ${ }^{1}$
}

${ }^{1}$ Department of Biological Sciences, University of Arkansas, Fayetteville, Arkansas, 72701, USA

Running title: Relationships between nutrient enrichment, detritus, and shredding invertebrates

${ }^{*}$ Corresponding author. Address: Department of Biological Sciences, Science and Engineering 601, University of Arkansas, Fayetteville, Arkansas, 72701, USA prater.clay@gmail.com, telephone: 479575 4706, fax: 4795754010

Author Contributions: $\mathrm{CP}$ and MAE conceived and designed the experiments. $\mathrm{CP}$ and EN collected and processed samples. CP and MAE analyzed the data and wrote the manuscript. 


\section{Abstract}

2 Anthropogenic nutrient enrichment of forested headwater streams can enhance detrital

3 quality, decrease standing stocks, and alter the community structure of detrivorous insects,

4 reducing nutrient retention and decreasing ecosystem functioning. Our objective was to

5 determine if stoichiometric principles could be used to predict genus-specific shifts in

6 shredding insect abundance and biomass across a dissolved nutrient and detritus food

7 quality/quantity gradient. Detritus, insect, and water samples were collected from 12 Ozark

8 Highland headwater streams. Significant correlations were found between stream nutrients

9 and detrital quality but not quantity. Abundance and biomass responses of four out of five

10 tested genera were accurately predicted by consumer-resource stoichiometric theory. Low

11 carbon:phosphorus $(\mathrm{C}: \mathrm{P})$ shredders responded positively to increased total phosphorus and/or

12 food quality, and high C:P shredders exhibited neutral or negative responses to these

13 variables. Genus specific declines were correlated with decreased overall biomass in shredder

14 assemblages, potentially causing disruptions in nutrient flows to higher level consumers with

15 nutrient enrichment. This work provides further evidence that elevated nutrients may

16 negatively impact shredding insect communities by altering the stoichiometry of detritus-

17 detritivore interactions. A better understanding of stoichiometric mechanisms altering

18 macroinvertebrate populations is needed to help inform water quality criteria for the

19 management of headwater streams.

20 Keywords: ecological stoichiometry, eutrophication, detritivore, leaf litter, shredder,

21 phosphorus 


\section{Introduction}

Anthropogenic nutrient enrichment is occurring worldwide (Kuijper et al. 2005) and is the second most common cause of freshwater ecosystem degradation in the US (EPA 2006). Headwater streams can have disproportionally high rates of nutrient processing compared to other freshwater systems (Alexander et al. 2000, Wollheim et al. 2001), and their destruction or degradation can decrease ecosystem functioning causing further downstream damage to rivers, lakes, and coastal areas (Carpenter et al. 1998). Forested headwater streams are increasingly imperiled due to the clearing of riparian vegetation for agricultural and urban area development (Paul \& Meyer 2001), which can cause amplified irradiance (DeNicola \& Hoagland 1996), flashier hydrology, increased sedimentation (Webster \& Waide 1982), and higher nutrient inputs (Likens et al. 1970) in these areas.

Recent studies have provided evidence that nutrient enrichment of forested headwater streams causes shifts in benthic macroinvertebrate community structure due to increases in detrital quality and decreases in quantity (Ramirez \& Pringle 2006, Cross et al. 2006, Greenwood et al. 2007, Singer \& Battin 2007). However, the relationship between altered diet and benthic macroinvertebrate community structure has not been examined across a regional stream nutrient gradient. Elevations of stream nutrient concentrations are known to differentially affect the quality and quantity of detrital material. Increased nutrients in the water column such as nitrogen $(\mathrm{N})$ and phosphorus $(\mathrm{P})$ can be immobilized by microbial decomposers (Webster et al. 2009), supporting higher rates of fungal and bacterial production, microbial respiration, and increased fungal biomass (Greenwood et al. 2007, Suberkropp et al. 2010). As detrital resources are generally poor in $\mathrm{N}$ and $\mathrm{P}$, increased microbial uptake can lead to increases in food quality, reducing nutritional imbalances between detritus and primary consumers (Cross et al. 2003, Greenwood et al. 2007, Hladyz et al. 2009). In turn, enhanced detrital quality can 
cause decreases in detrital standing stocks due to increased feeding by microbes and shredding macroinvertebrates (Rosemond et al. 2001). Therefore, unlike autotrophic systems, nutrient enrichment of detritus-based heterotrophic systems can accentuate $\mathrm{C}$ losses by stimulating C cycling rates in lower trophic levels of these systems (Rosemond et al. 2001, Cebrian 2004). Thus, increases in nutrient loading can alter basal resource nutrient quality ( $\mathrm{N}$ and P) and energy (C) quantity for detritivores adapted to forested headwater streams. Aquatic shredding insects have evolved in forested headwater streams under characteristically low nutrient conditions (Boersma \& Elser 2006). Undisturbed temperate headwater streams typically have high dissolved C:P and N:P ratios, potentially making these systems P-limited (Elwood et al. 1981). Therefore, these consumers have theoretically not evolved the ability to process excess $\mathrm{P}$ because of weak selective pressure for luxury Puptake (Boersma \& Elser 2006). Consequently, shredders with different life-history traits and stoichiometric needs could be differentially affected by changes in quality and quantity of their basal food resources induced by nutrient enrichment. For instance, slower growing, large-bodied, and high C:P consumers might be negatively affected and outcompeted by faster growing low C:P consumers (Danger et al. 2009), altering shredder assemblages in individual streams and across large regional scales.

Recent studies have highlighted the effects of anthropogenic P-loading on macroinvertebrate consumers and their food resources. Experimental reach-level studies have shown that increases in $\mathrm{P}$ concentrations can cause reductions in macroinvertebrate diversity, by reducing the nutrient imbalance between low $\mathrm{C}: \mathrm{P}$ consumers and their food resources (Singer \& Battin 2007, Gafner \& Robinson 2007). According to the growth rate hypothesis (Elser et al. 2003), low C:P consumers have a higher proportion of P-rich ribosomal ribonucleic acid (RNA) that allow them to grow faster and outcompete high C:P organisms under food P-saturation. These results, along with studies of experimentally enriched streams, 
have revealed increases in abundance, biomass, and secondary production of multivoltine Prich consumers (Cross et al. 2006, Davis et al. 2010, Small \& Pringle 2011). In addition, regional studies have found reductions in shredder and collector-gatherer macroinvertebrate community richness, diversity, and body C:P (Baldy et al. 2007, Wang et al. 2007, EvansWhite et al. 2009). These regional studies suggest that the community composition of aquatic organisms, especially those with large elemental imbalances between their diet and body composition, such as large-bodied high C:P shredding insects, can be negatively affected by high stream nutrient concentrations. However, these studies do not directly examine possible mechanistic changes in resource condition (i.e., increased food quality or decreased quantity) that might be responsible for observed changes in shredding insect community structure. The ability to predict the effects of altered detrital quality and quantity on life-history traits of individual long-lived shredder species and dynamics of whole assemblages could help establish more informed stream water nutrient criteria by estimating threshold responses of species abundance and biomass in response to nutrient enrichment. Estimates of threshold elemental ratios (TERs) combine information on consumer nutrient assimilation efficiencies and body nutrient composition to predict when growth limitation switches from one element to another. Furthermore, shredding macroinvertebrates generally have relatively high C:P TERs $\left(\right.$ TER $\left._{\mathrm{C}: \mathrm{P}}\right)$ compared to other functional feeding groups (Frost et al. 2006) and thus can be adversely affected by elevated P concentrations

93 Evans-White et al. 2009). Using stoichiometric insights, $\mathrm{TER}_{\mathrm{C}: \mathrm{P}}$ can be used to make logical 94 quantitative a priori predictions regarding shifts in natural populations and communities with nutrient enrichment. Unfortunately, very few direct measurements of element-specific assimilation or production efficiencies exist that would allow for calculation of $\mathrm{TER}_{\mathrm{C}: \mathrm{P}}$ for

97 many shredder species. However, as body C:P is positively related to TER $\mathrm{C}: \mathrm{P}$ (Frost et al. 
2006), we wanted to determine whether body C:P estimates may be used as a surrogate to qualitatively predict detritivore species responses to nutrient enrichment.

The first objective of this study was to determine if alteration of basal resource quality or quantity occurred across stream water total phosphorus (TP) and nitrate + nitrite-nitrogen $\left(\mathrm{NO}_{3}{ }^{-}+\mathrm{NO}_{2}{ }^{-}-\mathrm{N}\right)$ gradients. We predicted that coarse benthic organic matter (CBOM) nutritional quality would increase and that quantities would decrease with increased nutrient loading. Next, we examined whether stoichiometric principles (consumer/resource nutrient imbalance) could be used to predict genus-specific shifts in shredding insect abundance and biomass leading to alterations in overall insect community abundance and biomass. For these responses, we predicted that alteration in detrital quantity and/or quality would correlate with shifts in taxon dominance altering shredder communities, providing a mechanism for community composition shifts observed across larger regional scales (Wang et al. 2007, Evans-White et al. 2009). We specifically predicted that abundance and biomass of low C:P genera (Tipula spp., Pycnopsyche spp., and Ephemerella spp.) would increase with nutrient enrichment in this study and that high C:P consumer (Amphinumera spp. and Strophopteryx spp.) abundance and biomass would remain unchanged or that they would decrease across nutrient gradients. To examine whether these changes were related to differential investment of $\mathrm{P}$ to smaller-bodied fast growing life stages we analyzed community $\mathrm{C}: \mathrm{P}$ data and biomass:abundance ratios (B:A). We predicted that increased stream nutrient loading would enrich food quality shifting shredder community assemblages towards taxa with higher nutrient demands and that this would coincide with increased abundance of small-bodied consumers. We further predicted no significant differences in population level stoichiometry across streams but that shifts from high to low $\mathrm{C}: \mathrm{P}$ genera would result in significant reductions in shredder community $\mathrm{B}: \mathrm{A}$ and $\mathrm{C}: \mathrm{P}$ ratios due to the exclusion of larger-bodied high C:P shredders. 
Samples were collected between 20-Mar and 11-Apr 2009 (n=6 streams: water quality and detritus) and 2010 (n= 8 streams: water quality, detritus, and invertebrates) from

126 low-order headwater streams in the Ozark Highlands region of Northwest Arkansas, USA.

127 Samples were collected during these dates as they occurred prior to leaf out and during the

128 period of maximum invertebrate richness in this region (Evans-White et al. 2009). Land use

129 in watersheds was predominately forested $(34.0 \%-92.0 \%$; mean $=71.0 \%)$ and pastured areas

$130(4.0-52.0 \%$; mean $=20.0 \%)($ Table 1$)$, and mean stream width and depth was $5.5 \mathrm{~m}(2.0 \mathrm{~m}-$

$1319.3 \mathrm{~m})$ and $26.2 \mathrm{~cm}(4.0 \mathrm{~cm}-150 \mathrm{~cm})$, respectively. Dominant riparian vegetation was composed

132 of Red Oak (Quercus rubra), White Oak (Quercus bicolor), Sycamore (Platanus occidentalis), Sugar Maple (Acer saccharum), and River Birch (Betula nigra). Study streams substrata were primarily gravel and characterized by riffle-pool channel morphology

135 (Brussock et al. 1985). Two composite water samples, one filtered (glass fiber filter; $0.45 \mu \mathrm{m}$ mesh) and one unfiltered, were collected from the thalweg of a well-mixed region of each stream before sampling, kept on ice, and frozen upon returning to the lab. Turbidity was determined using a portable fluorometer (Turner Designs: Aquafluor 8000-010; Sunnyvale, CA) at the base of

140 each site, and dissolved oxygen (DO) was measured using a YSI probe (Model 95; Yellow

141 Springs, $\mathrm{OH})$. In the laboratory, filtered water samples were analyzed for $\mathrm{NO}_{3}{ }^{-}+\mathrm{NO}_{2}{ }^{-}-\mathrm{N}$

142 (Lachat QuikChem method 10-107-04-1-B, cadmium reduction), and ammonium $\left(\mathrm{NH}_{4}{ }^{+}\right)$

143 (Lachat QuikChem method 10-107-06-1-C, sodium hypochlorite), and unfiltered samples

144 were analyzed for TP (Thermo Scientific; Gensys 10vis, The Netherlands) using a persulfate 145 digestion followed by an ascorbic acid reduction method (APHA, 2005). Samples for CBOM quantity estimates were collected using a core and transect

147 approach to account for BOM patchiness in estimates (England \& Rosemond 2004). Samples 
were collected for CBOM nutrient analysis from three riffles and pools in each stream within

149 a 200m sampling reach. Dominant leaf species were obtained from the benthos in each

150 habitat unit, rinsed with stream water, placed into paper sacks, kept in a cooler on ice, and

151 immediately dried $\left(<50^{\circ} \mathrm{C} ; 24-48 \mathrm{~h}\right)$ upon returning to the lab.

152 Frozen CBOM samples collected with cores were thawed and picked through under a

153 dissecting scope to remove macroinvertebrates. Samples were then dried to a stable weight $(<$ $15450^{\circ} \mathrm{C}$ ), weighed, ashed at $550^{\circ} \mathrm{C}$, rehydrated, dried, and re-weighed to estimate ash free dry mass (AFDM). Dried CBOM nutrient content samples were ground to a fine powder using a Wig-L-Bug® grinder (Rinn, Crescent 3110B, Elgin, IL), and subsamples were analyzed for $\% \mathrm{P}, \mathrm{C}$, and $\mathrm{N}$. Leaf litter $\mathrm{P}$ content was determined by combusting the material at $550^{\circ} \mathrm{C}$ and incubating the material in $1 \mathrm{~N}$ hydrochloric acid for 30 minutes at $85^{\circ} \mathrm{C}$ (Rosemond 1993 , digest efficiency standard: NIST; Peach Leaves 1547, Gaithersburg, MD; \% recovery > 98\%). Following digestion, samples were diluted to $100 \mathrm{~mL}$ to neutralize $\mathrm{pH}$ and processed using an ascorbic acid reducing method (APHA 2005). Subsample C-and N-content was measured using a CHN elemental analyzer (EA Analytical; NC2500, Lakewood, NJ)

163 (combustion standard: Thermo Scientific; Aspartic Acid 338 40023, The Netherlands \% recovery $>99 \%$ ). All elemental ratios in this study are reported on a molar basis. within a 200m reach, according to rapid bioassesment protocols developed for multi-habitat

167 macroinvertebrate sampling (Barbour et al. 1999). Insects were sampled using a $250 \mu \mathrm{m}$ mesh

168 kick net. To ensure adequate sampling of all habitats within a habitat unit, ten kicks, covering an area of $0.2 \mathrm{~m}^{2}$, were made in each habitat, attempting to obtain samples from all subhabitats (along stream margins, thalweg, debris pools, etc.). Chironomids and two other rare taxa (Zealuctra spp. and Peltodytes spp.) were excluded from the present analysis, as their

172 abundance could not be accurately estimated using this collection procedure, and our study 
173 focused on slower growing long-lived shredders as potential indicators for long-term nutrient

174 stress. Insects were picked from the net in the field, placed in plastic cups containing stream

175 water, and transported back to the lab on ice. Insects were kept in growth chambers at $10^{\circ} \mathrm{C}$

176 overnight to allow gut evacuation. Afterword, insects were frozen until identification.

177 Shredders were thawed, rinsed, and identified to genus according to Merritt et al.

178 (2008) using a dissecting microscope. Abundances of each genus were tallied for each

179 individual riffle and pool, and lengths of each insect were measured to the nearest $0.1 \mathrm{~mm}$

180 using an ocular micrometer. Biomass for each genus was calculated for each habitat replicate

181 using length-mass conversions according to Benke et al. (1999). However, insects from the

182 genus Tipula spp. were individually dried and weighed to determine biomass. Genera

183 abundance and biomass estimates were calculated for separate riffles and pools, averaged

184 across each habitat at each site, and then used for shredder community analyses. All

185 abundance and biomass estimates are reported on a habitat-weighted basis. After

186 identification and measurement, genera from each habitat sample were pooled and analyzed

187 for C, N, P using methods reported above. Community C:P estimates were calculated from

188 the habitat-weighted means of each genus collected at each site.

All relationships between CBOM C:P and C:N, AFDM, and stream TP/ $/ \mathrm{NO}_{3}{ }^{-}+\mathrm{NO}_{2}{ }^{-}-\mathrm{N}$

190 were determined by Pearson and Spearman correlations. Differences in C:N and C:P body

191 content among individual genera were first assessed using one-way analysis of variance

192 (ANOVA) followed by Tukey-Kramer tests for unbalanced ANOVAs to confirm significant

193 differences between genera. Genus-specific responses to independent variables were first

194 analyzed using a nonparametric 2 dimensional Kolmogrov-Smirnov threshold analysis,

195 developed for detecting threshold change points for small sample sizes (Garvey 1998).

196 However, no threshold relationships were observed, so we further analyzed genera responses

197 using Pearson and Spearman correlations, after making Bonferroni corrections for multiple 
comparisons $(p<0.0125)$. First, we performed a Shapiro-Wilk test for normality, and we analyzed normally distributed data using Pearson correlations and non-normal data using Spearman correlations, according to the assumptions of each test. Relationships between shredder community abundance, biomass, $\mathrm{B}: \mathrm{A}$, and community $\mathrm{C}: \mathrm{P}$ ratio estimates and nutrient and detrital standing stock variables were determined by Pearson and Spearman correlations. All statistics were calculated using SAS statistical software, version 9.2 (SAS institute inc., Cary, NC.)

\section{Results}

turbidity was lower than values previously found to negatively affect macroinvertebrate communities in this region (Evans-White et al. 2009), ranging from 0.8-2.7 nephelometric turbidity units (NTU) (mean=1.5) (Table 1). The TP gradient ranged from 8-62 $\mu \mathrm{g} \mathrm{L}^{-1}$ $\left(\right.$ mean $\left.=27 \mu \mathrm{g} \mathrm{L}^{-1}\right)$. Levels of $\mathrm{NH}_{4}$ were low across all sites $5-30 \mu \mathrm{g} \mathrm{L}^{-1}\left(\right.$ mean $\left.=19.2 \mu \mathrm{g} \mathrm{L}^{-1}\right)$, and $\mathrm{NO}_{3}{ }^{-}+\mathrm{NO}_{2}{ }^{-}-\mathrm{N}$ concentrations ranged from low to potentially toxic levels $89-4,173 \mu \mathrm{g} \mathrm{L}^{-1}$

212 (mean= 1,179 $\left.\mathrm{\mu g} \mathrm{L}^{-1}\right)\left(\right.$ Camargo and Alonso 2006). Stream CBOM varied from 2-20 $\mathrm{g} \mathrm{m}^{-2}$ $213\left(\right.$ mean $\left.=8 \mathrm{~g} \mathrm{~m}^{-2}\right)$.

215 found across sites within years or when data from each year were combined $(p>0.05)$.

216 However, leaf litter C:P ratios were negatively correlated to water column TP concentrations 217 for both years considered separately $2009[(\mathrm{r}=0.88 ; p<0.01), 2010(\mathrm{r}=0.51 ; p=0.03)]$ and combined ( $\mathrm{r}=0.56 ; p<0.01)$ (Figure 1a). Significant decreases in leaf litter $\mathrm{C}: \mathrm{N}$ ratios with increases in stream $\mathrm{NO}_{3}{ }^{-}+\mathrm{NO}_{2}{ }^{-}-\mathrm{N}$ were also found in $2010(\mathrm{r}=0.50 ; p=0.03)$ and when both

220 years were considered together $(\mathrm{r}=0.54 ; p=0.01)$ (Figure $1 \mathrm{~b})$. However, no significant

221 correlation between $\mathrm{C}: \mathrm{N}^{2}$ and $\mathrm{NO}_{3}{ }^{-}+\mathrm{NO}_{2}{ }^{-}-\mathrm{N}$ existed in $2009(\mathrm{r}=0.07 ; p=0.31)$. 

region (Evans-White et al. 2009) and consisted of 7 shredder genera, across four orders, with body C:P ranging from 241-437 (mean= 354) and C:N from 6.2-8.2 (mean= 7.0) $($ Table 2). Only 2 individuals representing two rare taxa (Zealuctra spp. and Peltodytes spp.) were found in a single stream; therefore, we could not generate accurate stoichiometry and abundance/biomass data to include them in the analysis. Average abundance of the 5 focal taxa was: Tipula spp. $\left(2.01 \mathrm{~m}^{-2}\right)$, Pycnopsyche spp. $\left(0.81 \mathrm{~m}^{-2}\right)$, Ephemerella spp. $\left(3.51 \mathrm{~m}^{-2}\right)$, Amphinemura spp. $\left(5.21 \mathrm{~m}^{-2}\right)$, and Strophopteryx spp. $\left(0.52 \mathrm{~m}^{-2}\right)$. One-way ANOVA revealed a significant difference in $\mathrm{C}: \mathrm{P}$ and $\mathrm{C}: \mathrm{N}$ ratios for insects sampled in this study $(\mathrm{F}=7.17 ; \mathrm{df}=$ 4; $P<0.01, \mathrm{~F}=7.5 ; \mathrm{df}=4 ; P<0.01$, respectively). The two highest $\mathrm{C}: \mathrm{P}$ shredders' [Strophopteryx spp. and Amphinemura spp.] body stoichiometry differed significantly from the lowest C:P insect, Tipula spp. Significant differences were also found between the two highest C:N [ Strophopteryx spp. and Pycnopsyche spp.] and lowest C:N shredders (Tipula spp. and Ephemerella spp.) (Table 2). No insect genera responded to altered CBOM quantity; however, several correlations were found between shredder genera, water quality variables, and/or leaf litter stoichiometry (Table 3).

Four of the five genera measured responded significantly to differences in stream nutrients and/or leaf litter stoichiometry. As predicted, significant positive correlations were found between Pycnopsyche spp. abundance and TP (Figs. 2 C\&D) but not between this genus and any other variables. Ephemerella spp. stoichiometry fell in between our lowest and highest C:P taxa, but abundance and biomass revealed significant positive correlations with TP (Figs. 2 E\&F). Amphinemura spp., our second highest C:P taxon, showed no response to water or leaf litter chemistry (Figs. 3 A\&B). Abundance and biomass of our highest C:P taxon, Strophopteryx spp., showed positive correlations with leaf litter C:P and C:N (Figs. 3

246 C\&D), but did not respond to water column nutrients (Table 3). Counter to our predictions, 
the abundance and biomass of our lowest C:P genera, Tipula spp., exhibited a significant negative correlation with stream TP (Figs. 2 A\&B), and abundance was negatively correlated with stream $\mathrm{NO}_{3}{ }^{-}+\mathrm{NO}_{2}{ }^{-}-\mathrm{N}$ (Table 2). These genus-specific responses combined to shape overall shredder community structure.

Shredder community abundance was not significantly correlated to independent variables (Table 3; Fig. 4A). Biomass was negatively related with leaf litter C:P (Fig. 4B) but was not correlated with any other variables. We tested the prediction that average body size decreased as nutrients increased and leaf litter $\mathrm{C}: \mathrm{P}$ and $\mathrm{C}: \mathrm{N}$ decreased by examining relationships between these variables and B:A ratios. Ratios of shredder B:A were negatively correlated with TP (Table 3) and positively correlated to leaf litter C:P (Fig. 4C) and C:N (Table 3). However, no significant correlations were found for mean shredder community $\mathrm{C}: \mathrm{P}$ (Fig 4D), although the mean and variation in community $\mathrm{C}: \mathrm{P}$ tended to decrease with increasing TP and with decreasing leaf litter C:P (Table 3).

\section{Discussion}

To our knowledge, this study is the first to examine changes in shredding insect population and community abundance, biomass, and stoichiometry in conjunction with detritus standing stocks and resource stoichiometry across a multi-stream nutrient gradient. We provide correlative evidence collected across a nutrient gradient that shredding insect population responses to nutrient enrichment were related to differences in stream nutrients and detrital quality and independent of decreased detrital quantity. Further, shredding insect

267 population responses to enrichment were species dependent and generally predictable by shredding insect stoichiometry. These results taken together with results from manipulative enrichment experiments (Cross et al. 2003, 2006) provide a convincing body of evidence that changes in food quality may be in part responsible for shifts in macroinvertebrate community

271 structure with enrichment (Evans-White et al. 2009). 

nutrients across our study streams during the two years of study. The average leaf litter C:P $(2,088)$ and $\mathrm{C}: \mathrm{N}(41.0)$ fell between those given for leaf material found across a regional study conducted in Indiana, Michigan, and Wisconsin, US [(C:P 1,000); (C:N 25) EvansWhite et al. 2005] and those found in reference streams in North Carolina, US [(C:P=4,858); $(\mathrm{C}: \mathrm{N}=73$ ) Cross et al. 2003]. Microbial community biomass or activity was not measured in this study but likely increased with nutrient enrichment causing the observed trends in quality (Gulis \& Suberkropp 2003, Greenwood et al. 2007). Overall, evidence from this and many other studies (Cross et al. 2003, Greenwood et al. 2007, Small \& Pringle, 2010, Scott et al. 2013) indicates robust patterns of increased basal food resource quality in headwater detrital systems across time and space with nutrient loading, which may potentially alter macroinvertebrate assemblages.

We provided partial evidence for the food quality mechanism driving shifts in shredder populations and communities (ie. positive correlations between in high C:P Stophopteryx spp. and community biomass and food C:P), although water quality explained more of the variation than food quality in a majority of variables. It is possible that these shredders can selectively feed on more balanced C:P material (Hood et al. 2014), and this would weaken the overall response found in our study. Additionally, as detrital C:P depends on the initial C:P leaf litter inputs which can vary widely (Hattenschwiler et al 2008), differences among inputs to different sites could also weaken consumer-resource correlation.

292 However, our study indicates negative correlations between stream nutrients and resource

293 C:N and C:P. This evidence, along with food quality explaining a large amount of ecologically significant variance in shredder assemblages despite using a conservative statistical analysis in a highly variable field setting, suggests that food resource enrichment can have significant impacts on aquatic foodwebs. These changes could be due to either 
297 variation in nutrient content of plastic consumers or from decreases in sensitive invariable taxa experiencing nutrient stress.

Contradictory results have been found regarding the plasticity of consumer elemental

300 content in the lab and across nutrient gradients. Some studies have found significant

301 differences in taxa nutrient content when feeding across water quality or resource

302 stoichiometry gradients (Cross et al. 2003, Small \& Pringle 2010, Back 2008, 2013); however, others have found no deviation in elemental body composition (Evans-White et al. 2005, Danger et al. 2013). Our results most closely resemble Morse et al. 2012, as we found no significant differences in $\mathrm{P}$ content of any taxa across streams; however, two taxa (Tipula spp. and Strophopteryx spp.) in our study showed reduced body C:N with increased $\mathrm{NO}_{3}{ }^{-}$ $+\mathrm{NO}_{2}-\mathrm{N}$ (Supplementary Table 1). Due to the small sample sizes and taxonomic resolution of our study, comparisons to other studies should be taken with caution. Other differences in these studies are possibly due to differences in sample collection and processing (i.e. separating consumers by sex and size class vs. analyzing the population as a whole) as well as differences in elemental plasticity within a genus or between organisms in different regions. As a majority of taxa collected from the field displayed invariable body nutrient composition in our study, declines in sensitive taxa across nutrient gradients due to nutritional stress could significantly alter shredder assemblages.

316 in shredding insect biomass and abundance in four out of five genera including Tipula spp.,

317 Pycnopsyche spp., Ephemerella spp., and Strophopteryx spp. These patterns in abundance

318 and biomass at the genus level could generally be predicted by stoichiometry theory. Previous

319 stoichiometry research suggests that organisms with low body P contain lower RNA

320 quantities and therefore may not possess the molecular capabilities necessary to elicit a

321 significant growth response to food resource enrichment (Elser et al. 2000, Cross et al. 2003, 
322 Shade et al., 2003, Weider et al. 2005). In fact, metabolism of slower-growing low-P

323 organisms might be altered when consuming high-P resources, and this stress may cause

324 slower growth and altered life-history traits with resource enrichment (Boersma \& Elser

325 2006). Therefore, we expected to observe either no change or decreases in high body C:P

326 shredding insect species abundance and biomass as leaf litter C:P decreased and dissolved

327 nutrients increased. Examining patterns of the two highest C:P genera, we found that

328 Amphinemura spp. $(\mathrm{C}: \mathrm{P}=385)$ abundance and biomass did not change across the $\mathrm{TP}$ and leaf

329 litter C:P gradient suggesting that this species did not respond positively to increasing food

330 quality. Further, the abundance and biomass of our highest body C:P genera, Strophopteryx

331 spp. $(\mathrm{C}: \mathrm{P}=487)$, actually declined with increasing detrital food quality. This decline suggests

332 either that increasing levels of $\mathrm{P}$ in their food have some detrimental "stoichiometric knife-

333 edge" effect on Strophopteryx spp. populations (Boersma \& Elser 2006) or that some other

334 confounding factor is negatively affecting their populations.

335 While this study is correlative in nature and it is impossible to count out all potentially

336 confounding factors, these results reinforce the findings of negative relationships between

337 nutrient enrichment and sensitive shredding genera (Wang et al. 2007, Evans-White et al.

338 2009). If other factors such as increased turbidity or sedimentation were playing a significant

339 role shaping shredding macroinvertebrate populations in our most enriched sites, we would

340 expect most of our species to respond negatively to increasing TP as nutrient enrichment

341 correlates with these variables in this region (Evans-White et al. 2009). However,

342 Amphinemura spp. and Strophopteryx spp. did not respond to increasing TP, and

343 Ephemerella spp. $(\mathrm{C}: \mathrm{P}=321)$, and Pycnopsyche spp. $(\mathrm{C}: \mathrm{P}=340)$ responded positively,

344 confirming our prediction that lower body C:P shredders would respond positively to nutrient

345 enrichment. This evidence supports our prediction of shifting community structure to low C:P

346 organisms with nutrient enrichment; however, Tipula spp., the lowest C:P organism in our 
study declined with increased nutrients in this study, possibly due to other environmental or

348 life-history factors.

349 The resource quality hypothesis did not accurately predict patterns in abundance and 350 biomass for Tipula spp. Previous work at using experimental nutrient enrichment actually

351 found slight increases in Tipula spp. abundance, biomass, and production with $\mathrm{P}$ enrichment

352 of detrital resources (Cross et al. 2006 appendix a). However, as mean detrital C:P of the enriched stream of the previous study (3063) was much higher than in our region (2088), it is possible different responses between studies could point to Tipula spp. TER $\mathrm{C}_{\mathrm{C}: \mathrm{P}}$ falling within this range of litter enrichment or that unique species could respond differently to nutrient enrichment within this genera. Other factors such as [DO], stream drying, or water quality might also contribute to differences in population level responses on regional levels. However, we measured early morning [DO] in study streams during the winter and spring, and no streams were lower than $8.7 \mathrm{mg} \mathrm{L}^{-1}(80.3 \%)$. While this is only one time of year,

360 Tipula spp. are known to burrow into banks and enter diapause in mid-April/early May, and 361 abundance and biomass of this genus in Arkansas, US is not significantly affected by stream 362 drying (McCord et al. 2006). Finally, rapid bioassessment protocols suggest that Tipula spp. are more tolerant to degraded water quality than other taxa sampled in this study (Barbour et al. 1999). Mean tolerance values from the different regions were 5.8, 3.4, 1.9, 2.8, and 2.6 for Tipula spp., Pycnopsyche spp., Ephemerella spp., Amphinemura spp., and Strophopteryx

366 spp., respectively, with a score of zero being least tolerant and 10 being most tolerant.

367 Therefore, if other confounding pollutants were affecting shredder populations in our study, it 368 is not clear why Tipula spp. would be more sensitive than Strophopteryx spp. It is possible that differences in other life-history traits could be important factors controlling Tipula spp.

370 populations in this study. 

significantly to nutrient enrichment, whereas longer-lived semivoltine Tallaperla spp. stoneflies responded weakly under similar circumstances. Previous work conducted in the

374 Interior Highlands, US suggests that some tipulid species are semivoltine (Pritchard 1983,

375 McCord et al. 2006). Semivoltine life histories could put Tipula spp. at a competitive

376 disadvantage in headwater areas due to reductions of organic matter at key periods, such as

377 early fall, due to feeding of other quicker growing insect larvae (Cross et al. 2006). Intraguild competition could cause C-starvation in tipulids and explain the patterns of decreases in biomass and abundance, and declines in overall organic matter standing stocks could explain the differences in Tipula spp. abundance and biomass shifts between this study and others. As tipulids have been recognized as one of the major shredders in the Interior Highlands in terms of biomass (McCord et al. 2006), their sensitivity to nutrient enrichment could have significant impacts on detrital trophic processes in these systems. Lab-based studies are needed to further examine species-specific tipulid physiological responses to nutrient enrichment changes as their abundance and biomass were found to drive shifts in community patterns.

There was an overall decrease in large-bodied shredder biomass with increasing nutrient concentrations, and this shift combined with increased small-bodied consumers led to an overall decrease in community B:A ratios (Fig 4C). The finding of decreasing biomass differs from previous research that found overall positive relationships with P-enrichment

391 (Rosemond et al. 2002, Cross et al. 2006). In addition, we did not find a statistically significant relationship between mean shredder community C:P and leaf litter C:P (Fig 4D) or

393 TP in the present study, contrary to our predictions based on data from Evans-White et al.

394 (2009), which found negative correlations between community C:P and TP. However, we 395 found abundance and biomass increases in all but one low C:P taxa along with declines of the 
highest $\mathrm{C}: \mathrm{P}$ insects with increased stream TP, suggesting that declines in community $\mathrm{C}: \mathrm{P}$ with enrichment might occur in this region. Results from our study are not specifically comparable to previous studies however because we did not include low C:P multivoltine chironomids, which can come to dominate shredder production in enriched systems. Chironomids have been shown to exhibit variable body stoichiometry when feeding on resources in different streams (Small \& Pringle 2010), and increases in their biomass or feeding behavior could lead to altered detrital stoichiometry or standing stocks. Therefore, shifts from high to low C:P organisms may accompany enrichment, and chironomids could be superior competitors in high-P environments causing declines in shredder community $\mathrm{C}: \mathrm{P}$ and biomass (Baldy et al. 2007, Evans-White et al. 2009). Differences between studies highlight the need to consider life-history traits in addition to consumer stoichiometry when determining species responses to nutrient enrichment. Overall, this work suggests that while production might increase with nutrient enrichment (Cross et al. 2006), it comes at the expense of larger slow-growing taxa and that their absence may indicate nutrient enrichment of detrital resources. Further research into the physiology behind shredder knife-edge responses is needed to better understand the effects of dietary P saturation on slow-growing high $\mathrm{C}: \mathrm{P}$ consumers.

Our study revealed an overall pattern of altered shredder communities with increasing nutrient enrichment of detrital resources, possibly altering elemental flows through stream

415 foodwebs due to changes in consumer biomass. These shifts mostly favored lower C:P taxa, 416 as predicted by stoichiometric theory. The failure to accurately predict changes in Tipula 417 spp. populations highlights the need for more laboratory based measurements of differences 418 in invertebrate physiology under nutritional stress. More information gained by laboratory419 based TER estimates for shredding macroinvertebrates should improve predictive ability in 420 regards to stoichiometrically induced taxa shifts in aquatic environments. Information from 
421 species based TERs can be used to identify and predict dietary and physiological drivers of 422 species population shifts in natural assemblages, which could lead to decreased functional 423 diversity and community resilience in affected streams. This information combined with 424 nutrient threshold analysis has proven to be a powerful tool for predicting changes in 425 macroinvertebrate community structure on regional scales and should be used to inform 426 policy decisions for water quality standards (King \& Richardson 2003, Wang et al. 2007, 427 Evans-White et al. 2009) and for managing watersheds and stream networks on larger 428 regional and continental scales (King \& Baker 2010, Woodward et al. 2012).

\section{Acknowledgements}

430 We thank Brad Austin, Nicki Jenson, Olen Defoure, and Matt Holden who helped 431 with sample collection and/or processing and Thad Scott and Eric Pollock for the use of lab 432 equipment. Thad Scott, Sally Entrekin, Gary Huxel, and several anonymous reviewers 433 provided helpful comments on the manuscript. This research was funded by the National 434 Science Foundation (DEB-1020772 and REU-0755331). 


\section{References}

436 Alexander, R.B., R.A. Smith \& G.E. Schwarz, 2000. Effect of stream channel size on the delivery of nitrogen to the Gulf of Mexico. Nature 403: 758-761.

APHA. 2005 Standard methods for the examination of water and wastewater $21^{\text {st }}$ ed. Port City Press, Baltimore.

Back, J.A., J.M. Taylor, R.S. King, K.L. Fallert \& E.H. Hintzen, 2008. Ontogenic differences in mayfly stoichiometry influence growth rates in response to phosphorus enrichment. Fundamental and Applied Limnology 171: 233-240.

Back, J.A. \& R.S. King, 2013. Sex and size matter: ontogenetic patterns of nutrient content of aquatic insects. Freshwater Science 32: 837-848.

Baldy, V., V. Gobert, F. Guerold, E. Chauvet, D. Lambrigot \& J.Y. Charcosset, 2007. Leaf

Barbour, M.T., J. Gerritsen, B.D. Snyder \& J.B. Stribling, 1999. Rapid bioassessment protocols for use in streams and wadeable rivers: periphyton, benthic litter breakdown budgets in streams of various trophic status: effects of dissolved inorganic nutrients on microorganisms and invertebrates. Freshwater Biology 52: 1322-1335. macroinvertebrates, and fish, $2^{\text {nd }}$ edn. EPA 841-B-99-002 U.S. EPA, Washington, D.C.

Benke, A.C., A.D. Huryn, L.A. Smock \& J.B. Wallace, 1999. Lenth-mass relationships for freshwater macroinvertebrates in North America with particular reference to the Southeastern United States. Journal of the North American Benthological Society 18: 308-343.

Benstead, J.P., A.D. Rosemond, W.F. Cross, J.B. Wallace, S.L. Eggert, K, Suberkropp et al., 2009. Nutrient enrichment alters storage and fluxes of detritus in a headwater stream ecosystem. Ecology 90: 2556-2566. 
460 Boersema, M., \& J.J. Elser, 2006. Too much of a good thing: on stoichiometrically balanced diets and maximal growth. Ecology 87: 1325-1330.

462 Brussock, P.P., A.V. Brown \& J.C. Dixon, 1985. Channel form and stream ecosystem models. Journal of the American Water Resource Association 21: 859-866.

Camargo, J.A. \& A. Alonso, 2006. Ecological and toxicological effects of inorganic nitrogen 465 pollution in aquatic ecosystems: a global assessment. Environment International 32: 831-849.

Carpenter, S.R., N.F. Caraco, D.L. Correll, R.W. Howarth, A.N. Sharpley \& V.H. Smith, 1998. Nonpoint pollution of surface waters with phosphorus and nitrogen. Ecological Applications 8: 559-568.

Cebrian, J., 2004. Role of first-order consumers in ecosystem carbon flow. Ecology Letters 7: 232-240.

Cross, W.F., J.P. Benstead, A,D, Rosemond \& J.B. Wallace, 2003. Consumer-resource stoichimetry in detritus-based ecosystems. Ecology Letters 6: 721-732.

Cross, W.F., B.R. Johnson, J.B. Wallace \& A.D. Rosemond, 2005. Contrasting responses of stream detritivores to long-term nutrient enrichment. Limnology and Oceanography 50: $1730-1739$.

Cross, W.F., J.B.Wallace, A.D. Rosemond \& S.L. Eggert, 2006. Whole-system nutrient enrichment increases secondary production in a detritus-based ecosystem. Ecology 87: 1556-1565.

Cross, W.F., J.B. Wallace \& A.D. Rosemond, 2007. Nutrient enrichment reduces constraints on material flows in a detritus-based food web. Ecology 88: 2563-2575. composition of stream invertebrates a determinant of tolerance to organic pollution? Journal of the North American Benthological Society 28: 778-784. 
Danger, M., J.A. Funk, S. Devin, J. Heberle \& V. Felton, 2013. Phosphorus content in detritus controls life-history traits of a detritivore. Functional Ecology 27: 807-815.

Davis, J.M, A.D. Rosemond, S.L. Eggert, W.F. Cross \& J.B. Wallace, 2010. Long-term nutrient enrichment decouples predator and prey production. Proceedings of the National Academy of Sciences 107: 121-126.

DeNicola, M. \& K.D. Hoagland, 1996. Effects of solar spectral irradiance (visible to UV) on a prairie stream epilithic community. Journal of the North American Benthological Society 15: 155-169.

Eggert, S.L. \& J.B. Wallace, 2003. Litter breakdown and invertebrate detritivores in a resource-depleted Appalachian stream. Archive fur Hydrobiologie 156: 315-338.

Elser, J.J., R.W. Sterner, E. Gorokhova, W.F. Fagan, T.A. Markow, J.B. Cotner, et al., 2000. Biological stoichiometry from genes to ecosystems. Ecology Letters 3: 540-550.

Elser, J.J., K. Acharya, M. Kyle, J. Cotner, W. Makino, T. Markow, T. Watts, S. Hobbie, W. Fagan, J. Schade, J. Hood, \& R.W. Sterner. 2003. Growth rate-stoichiometry couplings in diverse biota. Ecology Letters 6: 936-943.

Elwood , J.W., J.D. Newbold, A.F. Trimble, \& R.W. Stark. 1981. The limiting role of phosphorus in a woodland stream ecosystem: effects of $\mathrm{P}$ enrichment on leaf decomposition and primary producers. Ecology 62:146-158.

England, L.E. \& A.D. Rosemond, 2004. Small reductions in forest cover weaken terrestrialaquatic linkages in headwater streams. Freshwater Biology 49: 721-734.

Evans-White, M.A., R.S. Stelzer \& G.A. Lamberti, 2005. Taxonomic and regional patterns in benthic macroinvertebrate elemental composition in streams. Freshwater Biology 50: 1786-1799.

Evans-White, M.A., W.K. Dodds, D.G. Huggins \& D.S. Baker, 2009. Thresholds in macroinvertebrate biodiversity and stoichiometry across water-quality gradients in 

28: $855-868$.

512 Frost, P.C., J.P. Benstead, W.F. Cross, H. Hillebrand, J.H. Larson, M.A. Xenopoulos, et al., 2006. Threshold elemental rations of carbon and phosphorus in aquatic consumers. Ecology Letters 9: 774-779.

Gafner, K. \& C.T. Robinson, 2007. Nutrient enrichment influences the responses of stream macroinvertebrates to disturbance. Journal of the American Bentholocial Society 26: $92-102$.

Garvey, J.E., E.A. Marschall \& R.A. Wright, 1998. From star charts to stoneflies: detecting relationships in continuous bivariate data. Ecology 79: 442-447.

Greenwood, J.L., A.D. Rosemond, J.B. Wallace, W.F. Cross \& H.S. Weyers, 2007. Nutrients stimulate leaf breakdown rates and detritivore biomass: bottom-up effects via heterotrophic pathways. Oecologia 151: 637-649.

Gulis, V. \& K. Suberkropp, 2003. Leaf litter decomposition and microbial activity in nutrient enriched and unaltered reaches of a headwater stream. Freshwater Biology 48: 123134.

Grime, J.P., 1973. Competitive exclusion in herbaceous vegetation. Nature 242: 344-347. in foliage and leaf litter chemistry among 45 tree species of a neotropical rainforest

530 Hood, J.M., C. McNeely, J.C. Finlay \& R.W. Sterner, 2014. Selective feeding determines patterns of nutrient release by stream invertebrates. Freshwater Science 33: 10931107. 
Hillebrand, H. \& V. Lehmpfuhl, 2011. Resource stoichiometry and consumers control the biodiversity-productivity relationship in pelagic metacommunities. The American Naturalist 178: 171-181.

Hladyz, S., M.O. Gessner, P.S. Giller, J. Pozo \& G. Woodward, 2009. Resource quality and stoichiometric constraints on stream ecosystem functioning. Freshwater Biology 54: 957-970.

King, R.S. \& C.J. Richardson, 2003. Integrating bioassessment and ecological risk assessment: an approach to developing numerical water-quality criteria. Environmental Management 31: 795-809.

King, R.S. \& M.E. Baker, 2010. Considerations for analyzing ecological community thresholds in response to anthropogenic environmental gradients. Journal of the North American Benthological Society 29: 998-1008.

Kuijper, L.D.J., M.P. Berg, E. Morrien, B.W. Kooi \& H.A. Verhoef, 2005. Global change effects on a mechanistic decomposer food web model. Global Change Biology 11: 249-265.

Likens, G.E., F.H. Bormann, N.M. Johnson, D.W. Fisher \& R.S. Pierce, 1970. Effects of forest cutting and herbicide treatment on nutrient budgets in the Hubbard Brook watershed-ecosystem. Ecological Monographs 40: 23-47.

McCord, S.B., A.D. Christian \& R.S. Grippo, 2006. Biomass dynamics of Tipula (Insecta: Diptera) in forested streams of the Interior Highlands, Arkansas. Journal of the Arkansas Academy of Sciences 60: 74-79.

Merritt, R.W., K.W. Cummins \& M.B. Berg, 2008. An introduction to the aquatic insects of North America, $4^{\text {th }}$ edn. Kendall Hunt, Dubuque. 
Morse, N.B., W.B. Wollheim, J.P. Benstead \& W.H. McDowell, 2012. Effects of suburbanization on foodweb stoichiometry of detritus-based streams. Freshwater Science 31: 1202-1213.

Paul, M.J. \& J.L Meyer, 2001. Streams in the urban landscape. Annual Review of Ecology and Systematics 32: 333-365.

Pritchard, G., 1983. Biology of Tipulidae. Annual Review of Entomology 28: 1-22.

Ramirez, A. \& C.M. Pringle, 2006. Fast growth and turnover of chironomid assemblages in response to stream phosphorus levels in a tropical lowland landscape. Limnology and Oceanography 51: 189-196.

Rosemond, A.D., P.J. Mulholland, \& J.W. Elwood, 1993. Top-down and bottom-up control of stream periphyton: effects of nutrients and herbivores. Ecology 74: 1264-1280.

Rosemond, A.D., C.M. Pringle, A. Ramirez \& M.J. Paul, 2001. A test of top-down and bottom-up control in a detritus-based food web. Ecology 82: 2279-2293.

Rosemond, A.D., C.M. Pringle, A. Ramírez, M.J. Paul \& J.L. Meyer, 2002. Landscape variation in phosphorus concentration and effects on detritus-based tropical streams. Limnology and Oceanography 47: 278-289.

Scott, E.E., C. Prater, E. Norman, B.C. Baker, M.A. Evans-White \& J.T. Scott, 2013. Leaflitter stoichiometry is affected by streamwater phosphorus concentrations and litter type. Freshwater Science 32: 753-761.

Shade, J.D., M. Kyle, S.E. Hobbie, W.F. Fagan \& J.J. Elser, 2003. Stoichiometric tracking of soil nutrients by a desert insect herbivore. Ecology Letters 6: 96-101.

Singer, G.A. \& T.J. Battin, 2007. Anthropogenic subsidies alter stream consumer-resource stoichiometry, biodiversity, and food chains. Ecological Applications 17: 376-389. 
Small, G.E. \& C.M. Pringle, 2010. Deviation from strict homeostasis across multiple trophic levels in an invertebrate consumer assemblage exposed to high chronic phosphorus enrichment in a Neotropical stream. Oecologia 162: 581-590.

Sterner, R.W. \& J.J. Elser, 2002. Ecological stoichiometry: the biology of elements from molecules to the biosphere, Princeton University Press, Princeton.

Suberkropp, K., V. Gulis, A.D. Rosemond \& J.P. Benstead, 2010. Ecosystem and physiological scales of microbial responses to nutrients in a detritus-based stream: results of a 5-year continuous enrichment. Limnology and Oceanography 55: 149-160.

U.S. EPA, 2006. Wadeable Streams Assessment- A Collaborative Study of the Nation's Streams. EPA 841-B-06-002., EPA, Washington D.C.

Wallace, J.B., M.R. Whiles, S.L. Eggert, T.F. Cuffney, G. Lugthart \& K. Chung, 1995. Longterm dynamics of coarse particulate organic matter in three Appalachian Mountain streams. Journal of the North American Benthological Society 14: 217-232.

Wallace, J.B., S.L. Eggert, J.L. Meyer \& J.L. Webster, 1997. Multiple trophic levels of a forest steam linked to terrestrial litter inputs. Science 277: 102-104.

Wang, L., D.M. Robertson \& P.J. Garisson, 2007. Linkages between nutrients and assemblages of macroinvertebrates and fish in the wadeable streams: implication to nutrient criteria development. Environmental Management 39: 194-212.

Webster, J.R. \& J.B. Waide, 1982. Effects of forest clear cutting on leaf breakdown in a southern Appalachian stream. Freshwater Biology 12: 331-334.

Webster, J.R., J.D. Newbold, S.A. Thomas, H.M. Valett \& P.J. Mulholland, 2009. Nutrient uptake and mineralization during leaf decay in streams- a model simulation. International Review of Hydrobiolgy 94: 372-390.

Weider, L.J., J.J. Elser, T.J. Crease, M. Mateos, J.B. Cotner \& T.A. Markow, 2005. The functional significance of ribosomal (r)DNA variation: impacts on the evolutionary 

219-242.

606 Wetzel, R.G., 1995. Death, detritus, and energy flow in aquatic ecosystems. Freshwater Biology 33: 83-89.

608 Wollheim, W.M., B.J. Peterson, L.A. Deegan, J.E. Hobbie, B. Hooker, W.B. Bowden et al., 2001. Influence of stream size on ammonium and suspended particulate nitrogen

610 processing. Limnology and Oceanography 46: 1-13.

611 Woodward, G., M.O. Gessner, P.S. Giller, V. Gulis, S. Hladyz, A. Lecerf et al., 2012.

612 Continental-scale effects of nutrient pollution on stream ecosystem functioning.

$613 \quad$ Science 336: 1438-1440.

614 
Table 1. Land use, water quality variables, and organic estimates for each site sampled. ${ }^{\mathbf{1}}$ Dissolved Oxygen, ${ }^{\mathbf{2}}$ Total Phosphorus, ${ }^{\mathbf{3}}$ Ammonium, ${ }^{\mathbf{4}}$ Nitrate + Nitrite-Nitrogen, ${ }^{5}$ Coarse Benthic Organic Matter.

\begin{tabular}{cccccccccc} 
Site & \multicolumn{2}{c}{ \% Land use } & \multicolumn{2}{c}{$\mathbf{D O}^{\mathbf{1}}$} & Turbidity & $\mathbf{T P}^{\mathbf{2}}$ & $\mathbf{N H}^{+\mathbf{3}}$ & $\mathbf{N O}_{\mathbf{3}}+\mathbf{N O}_{2}-\mathbf{N}^{\mathbf{4}}$ & $\mathbf{C B O M}^{\mathbf{5}}$ \\
& Forest & Pasture & $(\mathrm{mg} / \mathrm{L})$ & $(\%)$ & NTU & $(\mu \mathrm{g} / \mathrm{L})$ & $(\mu \mathrm{g} / \mathrm{L})$ & $(\mu \mathrm{g} / \mathrm{L})$ & $\mathrm{g}^{2} \mathrm{~m}^{2}$ \\
\hline Jones (09) & 90.0 & 6.6 & 9.14 & 93.3 & 2.7 & 8 & 17 & 534 & No Data \\
Sweet Water (09\&10) & 61.2 & 28.1 & 10.8 & 98.0 & 1.0 & 9 & 16 & 503 & 8 \\
Illinois (09\&10) & 61.2 & 28.1 & 10.5 & 93.3 & 0.9 & 9 & 29 & 653 & 4 \\
Cannon (10) & 81.6 & 12.5 & 10.7 & 95.1 & 1.0 & 16 & 5 & 772 & 20 \\
NFWOC (10) & 56.1 & 27.3 & 12.0 & 101.2 & 1.6 & 16 & 30 & 278 & 2 \\
Possum (09) & 90.2 & 6.5 & 10.8 & 97.4 & 1.1 & 20 & 12 & 146 & 2 \\
Fane (10) & 92.2 & 4.7 & 11.0 & 90.8 & 0.8 & 24 & 23 & 1220 & 6 \\
Ogden (09) & 87.6 & 7.4 & 10.2 & 95.9 & 2.2 & 26 & 24 & 89 & 17 \\
Crosses (09) & 81.6 & 12.5 & 10.7 & 98.4 & 2.4 & 41 & 16 & 317 & 6 \\
Wildcat (10) & 67.2 & 27.9 & 8.7 & 80.3 & 1.9 & 49 & 21 & 3901 & 13 \\
Flint (10) & 34.9 & 52.7 & 10.4 & 94.4 & 1.2 & 50 & 22 & 4173 & 4 \\
Chambers (10) & 58.7 & 36.2 & 10.4 & 88.6 & 1.7 & 62 & 15 & 1567 & 7
\end{tabular}


Table 2. Shredding insect genera and mean ${ }^{\mathbf{1}}$ carbon:phosphorus $(\mathrm{C}: \mathrm{P})$ and ${ }^{\mathbf{2}}$ carbon:nitrogen $(\mathrm{C}: \mathrm{N})$ molar ratios \pm standard deviation. Letters indicate species separated using TukeyKramer tests for significant differences $(P<0.01)$ between shredding genera $\mathrm{C}: \mathrm{P}$ and $\mathrm{C}: \mathrm{N}$.

$\begin{array}{cccccc}\text { Order } & \text { Family } & \text { Genus } & \text { Sample \# } & \text { C:P1 } & \text { C:N } \mathbf{N}^{\mathbf{2}} \\ \text { Diptera } & \text { Tipulidae } & \text { Tipula spp. } & 39 & 241 \pm 41^{\mathrm{a}} & 6.3 \pm .052^{\mathrm{ac}} \\ \text { Tricoptera } & \text { Limnephilidae } & \text { Pycnopsyche spp. } & 11 & 321 \pm 55^{\mathrm{a}} & 7.8 \pm 1.04^{\mathrm{b}} \\ \text { Ephemeroptera } & \text { Ephemerellidae } & \text { Ephemerella spp. } & 13 & 340 \pm 68^{\mathrm{a}} & 6.2 \pm 0.24^{\mathrm{ac}} \\ \text { Plecoptera } & \text { Nemouridae } & \text { Amphinemura spp. } & 20 & 385 \pm 86^{\mathrm{b}} & 7 \pm 0.48^{\mathrm{abc}} \\ \text { Plecoptera } & \text { Taeniopterygidae } & \text { Strophopteryx spp. } & 8 & 437 \pm 54^{\mathrm{b}} & 8.2 \pm 1.4^{\mathrm{b}}\end{array}$


Table 3. Results of correlation analysis between dependent and independent variables. Pearson and Spearman correlations are expressed as $r$ and $p$-values. Significant relationships are presented in bold font after Bonferroni corrections for multiple comparisons $(p<0.0125) .{ }^{1}$ Total Phosphorus, ${ }^{2}$ Nitrate + Nitrite-Nitrogen, ${ }^{3}$ Leaf litter carbon:phosphorus ratio, ${ }^{4}$ Leaf litter carbon:nitrogen ratio ${ }^{5}$ Biomass:abundance ratio,

${ }^{6}$ Community carbon:phosphorus ratio.

\begin{tabular}{|c|c|c|c|c|}
\hline & $\begin{array}{c}\mathbf{T P}^{\mathbf{1}} \\
(\mu \mathrm{g} / \mathrm{L})\end{array}$ & $\begin{array}{c}\mathbf{N O}_{3}{ }^{-}+\mathbf{N O}_{2}-\mathbf{N}^{2} \\
(\mu \mathrm{g} / \mathrm{L})\end{array}$ & $\begin{array}{c}\text { Leaf } \mathbf{C}: \mathbf{P}^{\mathbf{3}} \\
\text { Molar Ratio }\end{array}$ & $\begin{array}{c}\text { Leaf C: } \mathbf{N}^{4} \\
\text { Molar Ratio }\end{array}$ \\
\hline Community Abundance & $0.76 ; 0.03$ & $0.55 ; 0.16$ & $-0.64 ; 0.09$ & $-0.55 ; 0.16$ \\
\hline Community Biomass & $-0.78 ; 0.02$ & $-0.69 ; 0.06$ & $0.82 ; 0.01$ & $0.81 ; 0.01$ \\
\hline Community B: $\mathrm{A}^{5}$ & $0.85 ;<0.01$ & $-0.67 ; 0.07$ & $0.67 ;<0.01$ & $0.86 ;<0.01$ \\
\hline Community $\mathrm{C}: \mathrm{P}^{3}$ & $0.02 ; 0.97$ & $-0.31 ; 0.46$ & $-0.19 ; 0.66$ & $-0.24 ; 0.57$ \\
\hline Tipula spp. Abundance & $-0.88 ;<0.01$ & $-0.83 ;<0.01$ & $0.55 ; 0.16$ & $0.64 ; 0.09$ \\
\hline Tipula spp. Biomass & $-0.81 ; 0.01$ & $-0.76 ; 0.03$ & $0.57 ; 0.14$ & $0.62 ; 0.10$ \\
\hline Pycnopsyche spp. Abundance & $0.83 ; 0.01$ & $0.27 ; 0.52$ & $-0.51 ; 0.19$ & $-0.56 ; 0.15$ \\
\hline Pycnopsyche spp. Biomass & $0.76 ; 0.03$ & $0.15 ; 0.73$ & $-0.47 ; 0.24$ & $-0.48 ; 0.23$ \\
\hline Ephemerella spp. Abundance & $0.96 ;<0.01$ & $0.80 ; 0.02$ & $-0.77 ; 0.03$ & $-0.77 ; 0.03$ \\
\hline Ephemerella spp. Biomass & $0.90 ;<0.01$ & $0.81 ; 0.02$ & $-0.78 ; 0.02$ & $-0.81 ; 0.02$ \\
\hline Amphinemura spp. Abundance & $-0.02 ; 0.96$ & $-0.12 ; 0.78$ & $-0.36 ; 0.39$ & $-0.36 ; 0.38$ \\
\hline Amphinemura spp. Biomass & $-0.36 ; 0.39$ & $-0.36 ; 0.39$ & $-0.16 ; 0.70$ & $-0.20 ; 0.64$ \\
\hline Strophopteryx spp. Abundance & $-0.46 ; 0.25$ & $-0.33 ; 0.43$ & $0.82 ; 0.01$ & $0.61 ; 0.01$ \\
\hline Strophopteryx spp. Biomass & $-0.48 ; 0.23$ & $-0.14 ; 0.75$ & $0.83 ; 0.01$ & $0.84 ;<0.01$ \\
\hline
\end{tabular}


Fig. 1 Correlations between total phosphorus (TP) and leaf litter carbon:phosphorus (C:P) and between $\mathrm{NO}_{3}{ }^{-}+\mathrm{NO}_{2}{ }^{-}-\mathrm{N}$ and leaf litter carbon:nitrogen $(\mathrm{C}: \mathrm{N})$ in 2010. Results of Pearson and Spearman correlations are expressed as $\mathrm{r}$ and $p$-values.

Fig. 2 Correlations between Tipula spp., Pycnopsyche spp., and Ephemerella spp. abundance and biomass and total phosphorus (TP). Results of Pearson and Spearman correlations are expressed as $r$ and $p$-values.

Fig. 3 Correlations between Amphinemura spp.and Strophopteryx spp. abundance and biomass and leaf litter carbon:phosphorus (C:P). Results of Pearson and Spearman correlations are expressed as $\mathrm{r}$ and $p$-values.

Fig. 4 Relationships between shredding insect community abundance, biomass, community biomass:abundance ratios (B:A), community carbon:phosphorus $(\mathrm{C}: \mathrm{P})$ ratios, and leaf litter C:P. Results of Pearson and Spearman correlations are expressed as $\mathrm{r}$ and $p$-values. 
Figure 1
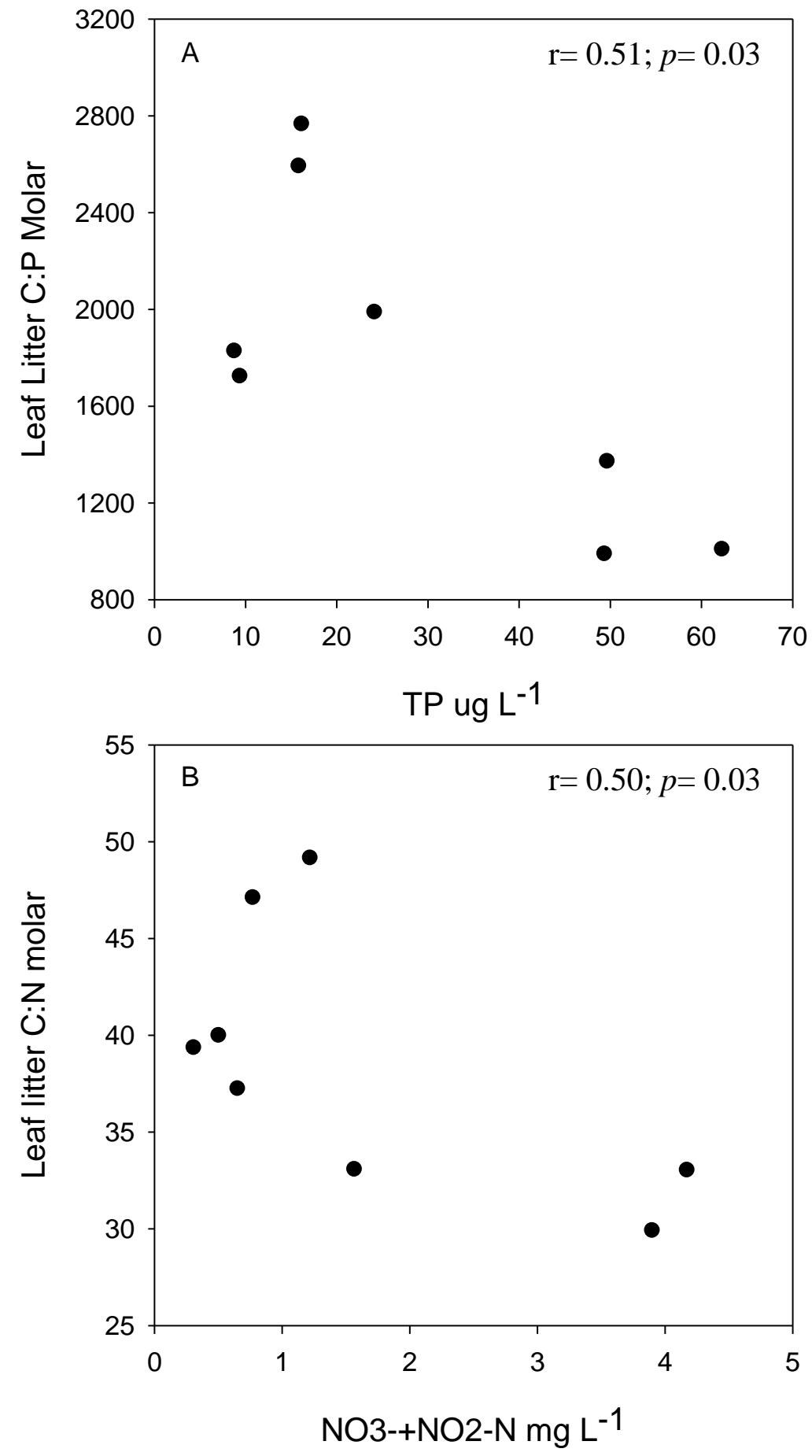
Figure 2
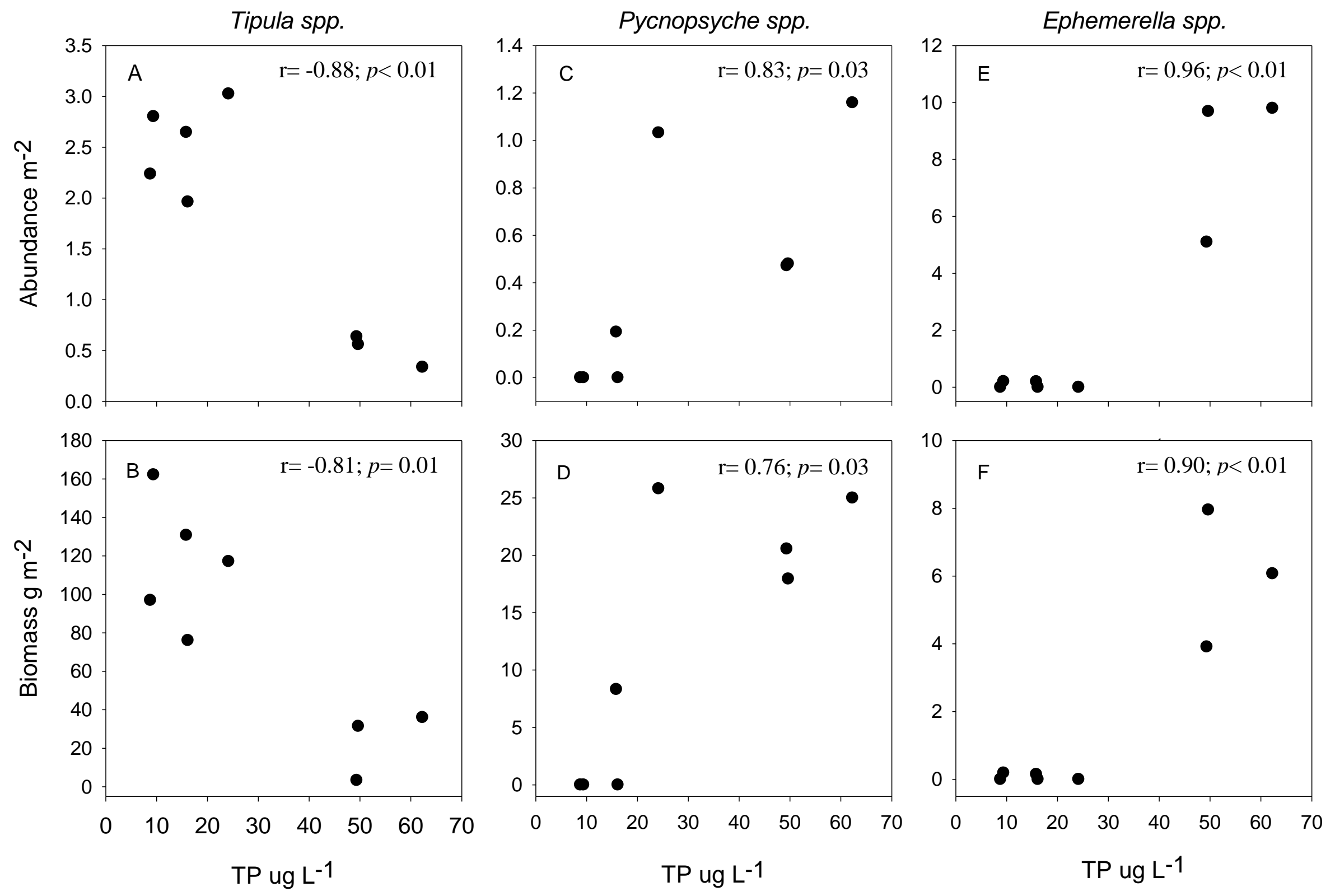
Figure 3

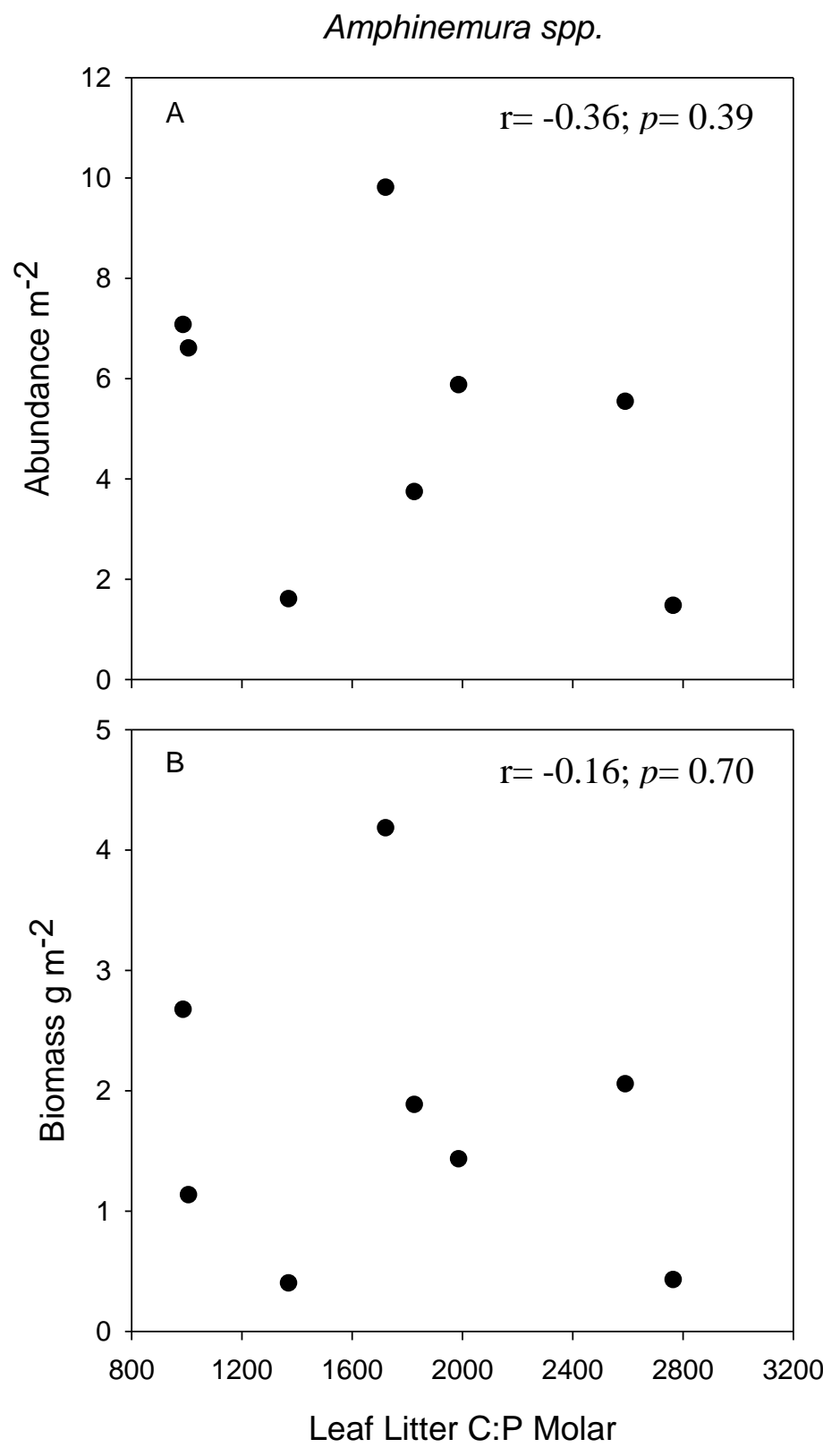

Strophopteryx spp.
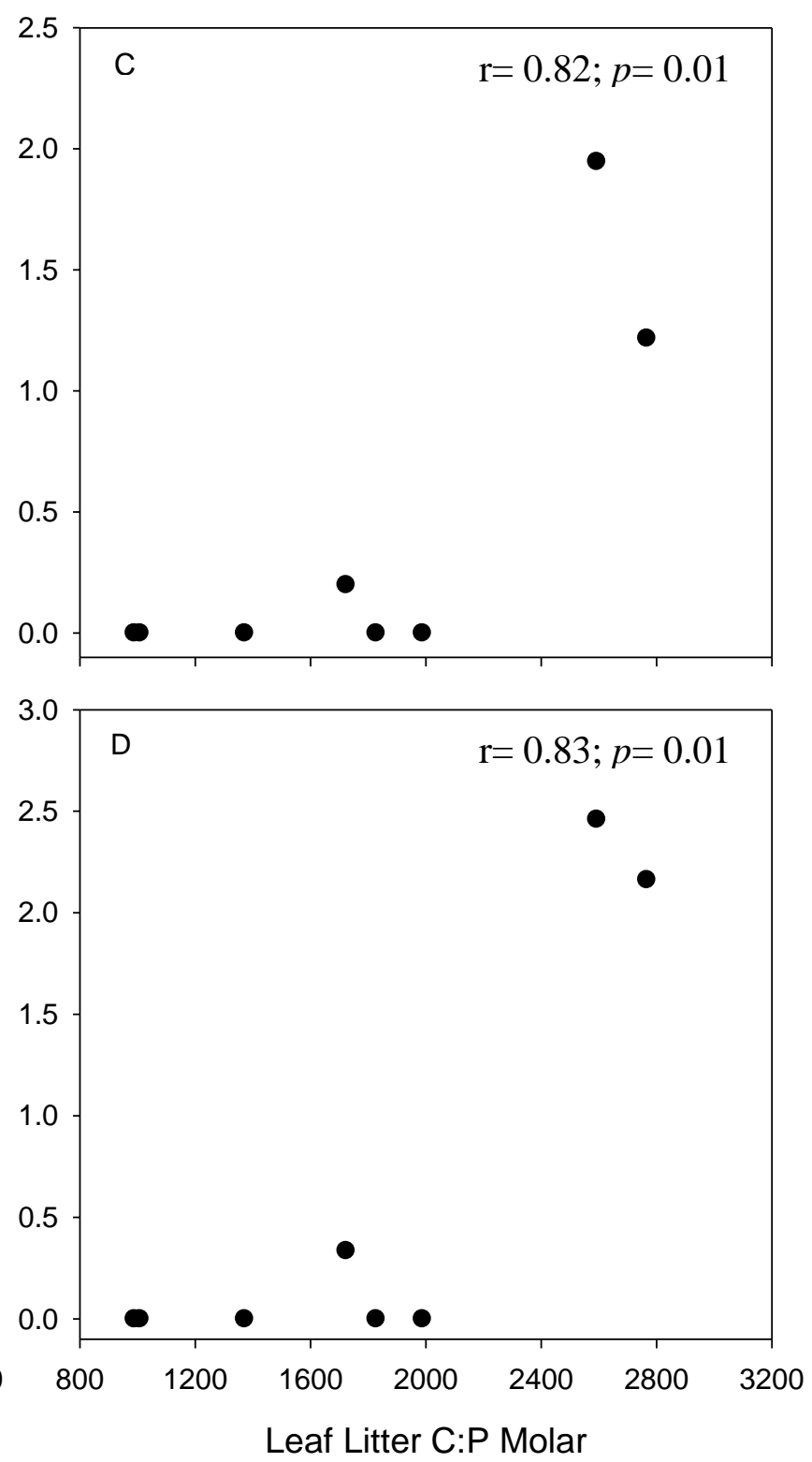
Figure 4
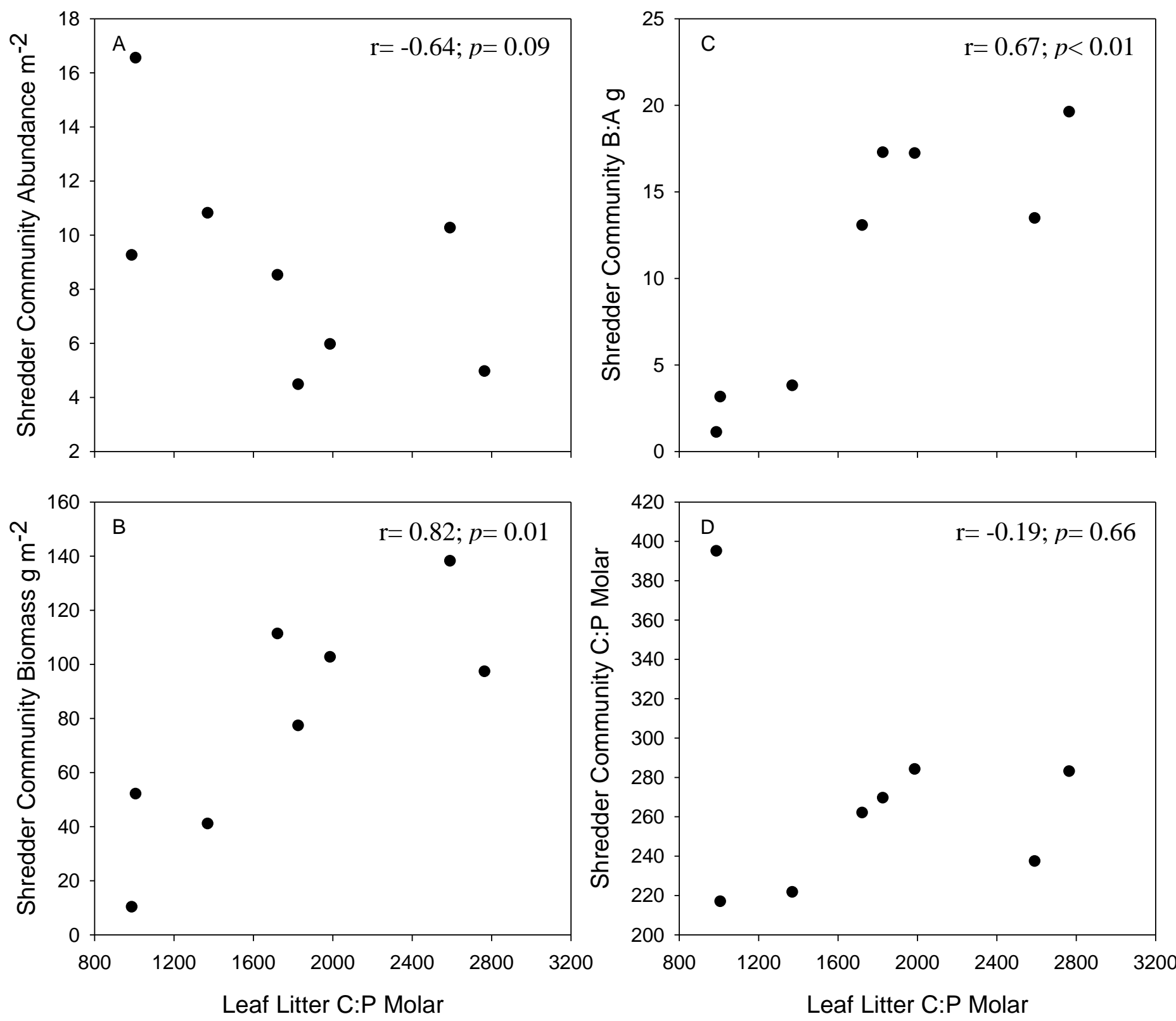